\title{
On the Occasion of the Tenth Anniversary of the Establishment of the Embassy of Mexico in Saint Lucia
}

\author{
Timothy Harris \\ Prime Minister of St Kitts and Nevis
}

t gives me great pleasure to be able to contribute to this special issue of Ithe Revista Mexicana del Caribe. As I reflect on the excellent relations that the Governments and peoples of St. Kitts and Nevis and Mexico have long enjoyed, since establishing diplomatic relations in 1990, I am particularly satisfied with the progress we have made over the last decade, largely attributed to the opening of the Embassy of Mexico in Castries. With concurrent accreditation to Member States and the Organisation of Eastern Caribbean States (OECS), this has augured well for increased dialogue and commercial and cultural collaboration between our countries. In St. Kitts and Nevis, these bonds were further solidified in May 2015 when the Government of Mexico opened a consulate in Basseterre and appointed an honorary consul in the person of Mr. José Rosa Santory to represent the interests of the small but growing Mexican population, as well as the increasing number of tourists from Mexico who come to our Federation every year.

The Caribbean region has long been an important facet of the foreign policy of Mexico, and today it is a great privilege for St. Kitts and Nevis to have benefitted on the bilateral and multilateral fronts from numerous cooperation projects and large disbursements of funds from the Mexican Government, as well as from the Infrastructure Fund for Mesoamerican and Caribbean countries. We are indeed very grateful to the Mexican Government and people for their assistance and commitment to our economic and social development. Your robust contribution to St. Kitts and Nevis in the area of education is highly appreciated. As the great Nelson Mandela said, "Education is the most powerful weapon which you can use to change the world," and it is quite apparent that Mexico understands this, as the Mexican Government consistently provides scholarship opportunities to international students including nationals of St. Kitts and Nevis, to pursue courses 
in Diplomacy, the teaching of Spanish, Hydrography as well as master's and doctorate degrees specializing in Tourism, Transportation, Trade, and Natural Disasters.

I am indeed most proud to add that we now have five young professionals contributing positively to our nation building efforts in the public and private sector, who were all recipients of Mexican scholarships and who have all graduated from Mexican Universities with Bachelor's degrees in Economics, International Relations, Tourism Management, Agronomy and Linguistics respectively. Additionally, our Ministry of Education was the beneficiary of scores of books from Mexican and Latin American authors covering a wide array of topics. These were in turn shared with public libraries for the benefit of the entire population.

Importantly, our two Governments have been able to cooperate in the area of security. In 2006, both Governments signed a Memorandum of Understanding for the construction of two police stations in the rural areas of Dieppe Bay and Tabernacle. These capital projects are vital to the Government in its efforts to enhance security and build capacity in law enforcement. The projects were completed in 2011 and 2014, respectively.

Similarly, our two Governments have been able to cooperate in the area of security. In 2006, both Governments signed a Memorandum of Understanding for the construction of two police stations in the rural areas of Dieppe Bay and Tabernacle. These capital projects are vital to the Government in its efforts to enhance security and build capacity in law enforcement. The projects were completed in 2011 and 2014, respectively.

The Ministry of International Trade has been the recipient of expert assistance in the establishment of a business incubator, aimed at increasing opportunities for commerce and promoting entrepreneurial enterprise in our Federation.

However, our collaboration in the regional, hemispheric and international area remains vibrant. Both our countries share common values, rooted in democracy, justice and equality for all, and the rule of law. We therefore often share similar views in multilateral fora such as the United Nations, the Organisation of American States, The Community of Latin American and Caribbean States (CELAC) and the Association of Caribbean States (ACS). 
The Government of St. Kitts and Nevis has supported many Mexican candidatures over the last ten years for membership in international organisations. Most recently was the support for Mr. Arturo López Portillo Contreras for the position of Director of Disaster Risk Reduction and Transport of the ACS during the 7th Summit of the ACS which recently concluded in Havana, Cuba.

The Mexico-CARICOM Summit, initiated in 2010 provides a forum for political high-level engagement for increased collaboration between both sides and St. Kitts and Nevis has always been an active participant.

I believe that the strong bonds of friendship are not only evident between our Governments but also between our people. Latin Fiesta, a local and annual event designed to promote the arts and culture of Latin American people in the Federation is yet another celebrated opportunity that affirms our nation's closeness with Mexico and the rest of Latin America. Last year, Mexico was the featured country. In addition to showcasing Mexican cuisine and music, nationals and visitors also enjoyed a Mexican movie night featuring 'Norteado' directed by Rigoberto Perezcano.

Our people to people contact is also gaining pace. There is an increasing population of Mexicans resident in our Federation, contributing to our local economy especially in the Construction and Hospitality Industries, critical areas for St. Kitts and Nevis with tourism as a major contributor to the economy. With specialised skills, Mexicans comprise the labour force on some hotel construction sites on the South East Peninsula of the island of St Kitts. Additionally, two Mexican restaurants offering Mexican cuisine are frequented by both tourists and locals alike. These eateries have created and enhanced variety in the culinary aspect of our culture. Further, the Dolphin Discovery Park, an added tourist attraction, opened in December 2014, is owned and operated by Mexicans.

The Government of St Kitts and Nevis is committed to continuing the strong bilateral ties between our Government and that of Mexico and we look forward to celebrating another decade, replete with increased cooperation to our mutual advantage. 